\title{
Parasite community of Pagrus pagrus (Sparidae) from Rio de Janeiro, Brazil: evidence of temporal stability
}

A comunidade de parasitos metazoários de Pagrus pagrus (Sparidae) do Rio de Janeiro, Brasil: evidências de estabilidade temporal

Iris Aparecida Soares'; Fabiano Matos Vieira²; José Luis Luque²*

${ }^{1}$ Curso de Pós-graduação em Ciências Veterinárias, Universidade Federal Rural do Rio de Janeiro - UFRRJ, Seropédica, RJ, Brasil

${ }^{2}$ Departamento de Parasitologia Animal, Universidade Federal Rural do Rio de Janeiro UFRRJ, Seropédica, RJ, Brasil

Received February 14, 2014

Accepted March 11, 2014

\begin{abstract}
One hundred specimens of Pagrus pagrus were necropsied for parasitological study between January and February 2012. These data were compared with data from 90 specimens that had been examined in the year 2000 . The fish were collected from Cabo Frio $\left(21-23^{\circ} \mathrm{S}, 41-45^{\circ} \mathrm{W}\right)$, in the state of Rio de Janeiro, Brazil. In the current study a total of 19 parasite species were collected. Sixteen of these were collected in the samples of both 2012 and 2000, thus totaling 25 parasite species in the two studies. All the results were similar to those of the previous study with regard to: dominance of anisakid nematode larvae; correlation between abundance of parasites and host body size; absence of correlations between the size of parasite infrapopulations and host sex; and scarcity of interspecific associations. The only difference between the studies was in the abundance values for Anisakidae, which could be correlated with the seasonal factor of the collection period, which was concentrated in the summer. This is also the period of the South Atlantic Central Water (SACW) phenomenon, during which there is greater host reproductive activity. Therefore, significant stability of the metazoan community structure of $P$. pagrus was shown.
\end{abstract}

Keywords: Pagrus pagrus, parasites, community structure, marine fish, temporal stability.

\section{Resumo}

Cem exemplares de Pagrus pagrus foram necropsiados entre janeiro e fevereiro de 2012 para estudos parasitológicos. Esses dados foram comparados com dados de 90 espécimes examinados no ano 2000. Os peixes foram coletados em Cabo Frio (21-23 $\left.{ }^{\circ} \mathrm{S}, 41-45^{\circ} \mathrm{W}\right)$, no Estado do Rio de Janeiro, Brasil. No presente estudo, foram coletados um total de 19 espécies de parasitos, 16 delas foram coletadas em comum nas amostras de 2012 e 2000, dando um total de 25 espécies de parasitos. Todos os resultados foram semelhantes aos do estudo anterior em: dominância das larvas de anisaquídeos; correlaçáo entre a abundância de parasitos e comprimento total do corpo dos hospedeiros; ausência de correlações entre o tamanho das infrapopulações parasitárias e sexo do hospedeiro e a escassez de associações interespecíficas. A única diferença entre os estudos reside nos valores da abundância de nematóides anisaquídeos, o que poderia ser correlacionado com o fator sazonal do período de coleta que foi concentrada no veráo, período que coincide com o fenômeno da Água Central do Atlântico Sul (ACAS), no qual o hospedeiro apresenta maior atividade reprodutiva. Portanto, uma significativa estabilidade da estrutura da comunidade de parasitos de P. pagrus foi evidenciada.

Palavras-chave: Pagrus pagrus, parasitas, estrutura da comunidade, peixe marinho, estabilidade temporal.

\section{Introduction}

Pagrus pagrus (Linnaeus, 1758) (Perciformes: Sparidae), popularly known as red porgy, is a demersal fish that feeds on a wide variety of benthic and other demersal fish, and invertebrates (ÁVILA-DA-SILVA; HAIMOVICI, 2004). This species is widely distributed in the Eastern Atlantic from the British Isles south to

\footnotetext{
${ }^{*}$ Corresponding author: José L. Luque

Departamento de Parasitologia Animal, Universidade Federal Rural do Rio de Janeiro - UFRRJ, CP 74540, CEP 23851-970, Seropédica, RJ, Brasil

e-mail: luqueufrrj@gmail.com
}

the coastal zone of Angola, and also in the Mediterranean and the Adriatic Sea. In the Western Atlantic, P. pagrus is distributed from the coast of New York, USA, to southern Argentina (MANOOCH; HASSLER, 1978; MENEZES; FIGUEIREDO, 1980).

Pagrus pagrus is a fish of significant commercial value, particularly for export. It is caught using various devices at fishing depths of up to $200 \mathrm{~m}$ (ÁVILA-DA-SILVA; HAIMOVICI, 2004). In Brazil, this species is widely distributed along the coast of southeastern to southern regions (ÁVILA-DA-SILVA; HAIMOVICI, 2004). 
Currently, $P$. pagrus is included in the list of endangered species (IUCN, 2013).

To date, 29 species of parasites of $P$. pagrus distributed among Nematoda, Digenea, Monogenea, Cestoda, Acanthocephala and Copepoda have been recorded in Brazil (LUQUE; TAVARES, 2007; KOHN et al., 2007; MUNIZ-PEREIRA et al., 2009; LUQUE et al., 2011; COHEN et al., 2013). Nematodes are the most numerous parasite group in this host, with nine recorded species (LUQUE et al., 2011). In Brazil, a description of the structure of the parasite communities of $P$. pagrus was previously published by Paraguassú et al. (2002).

Communities of parasites of marine fish are often unstructured and unpredictable because the vagility, behavior, physiology and feeding habits of the hosts, as well as the phylogenetic specificity and possible interactions between parasites (LUQUE, 2004; LUQUE; POULIN, 2008). A large number of studies have focused on the structure of parasite communities of marine fish. However, many of them do not address spatial-temporal variations or the determination of local processes and those of short duration that may affect the spatial-temporal dynamics of parasite populations and communities (POULIN; VALTONEN, 2002).

The aim of this study was to detect possible changes in the structure of the communities of metazoan parasites of $P$. pagrus after a long time period (12 years) on the coast of the state of Rio de Janeiro, Brazil.

\section{Materials and Methods}

We examined 100 specimens of $P$. pagrus collected between January and February 2012. Data from this study were compared with data from 90 specimens studied by Paraguassú et al. (2002), using the original raw data used in that study. In both studies, the fish were caught in the coastal zone of Cabo Frio, state of Rio de Janeiro (22 52 ' $43^{\prime \prime}$ S, $\left.42^{\circ} 1^{\prime} 12^{\prime \prime} \mathrm{W}\right)$, Brazil. The host species were identified in accordance with Menezes and Figueiredo (1980).

The analysis included only parasite species with prevalence higher than 10\% (BUSH et al., 1990). The Spearman rank correlation coefficient ( $r s$ ) was calculated to determine possible correlations between host length and total abundance of parasites. The Pearson correlation coefficient $r$ was used as an indication of the relationship between the total length of the host and parasite prevalence, with further prior processing of prevalence data (ZAR, 1996). The Student $t$ test was used to make comparisons with data from Paraguassú et al. (2002), in order to ascertain whether the relationships remained the same after 12 years. This test was used for statistical comparisons between the quantitative characteristics of the metazoan infracommunities, using data from Paraguassú et al. (2002). The species diversity of the parasite was calculated using the Brillouin index $(\mathrm{H})$, given that each fish analyzed corresponded to a full sample community (ZAR, 1996), so as to ascertain whether the diversity values remained similar after 12 years. The likely variation in sex-related host diversity was analyzed using the Mann-Whitney $U$ test, and the host total length was tested using the Spearman correlation coefficient, and the results were compared with the study of Paraguassú et al. (2002). The possible interspecific association between the competing species was determined using the chi-square test. Possible covariance between the abundance of competing species was analyzed using the Spearman correlation coefficient to check whether the same associations were detected 12 years after the study of Paraguassú et al. (2002). The ecological terminology was used in accordance with Bush et al. (1997). Chi-square analyses were used to test significant differences in the prevalence of parasites between the two samples and the Mann-Whitney test was used for comparison of parasite abundances. The statistical significance level was set at $P<0.05$.

Non-metric multidimensional scaling (NMDS) based on the Bray-Curtis similarity index was used to rank the infracommunity metazoan parasites of the current study and make comparisons with the data of Paraguassú et al. (2002), according to their relative similarities in parasite abundances. This analysis was performed using 100 random departures with two and three-dimensional configurations in order to find the optimum ranking. All the methods yielded similar results, but three-dimensional ranking based on the transformation $\log (\mathrm{x}+1)$ was ultimately chosen because it provided the best quality ranking (assessed using the stress value and inspection of Sheppard plots). One-way analysis of similarity (ANOSIM) was used to determine the significance of possible grouping patterns in the NMDS ranking (CLARKE, 1993). Percentage similarity-contribution of species (SIMPER) was used to define the contribution of the species within and among groups (current study and Paraguassú et al. (2002)) shown in the NMDS (CLARKE; WARWICK, 2001). A cumulative contribution of $80 \%$ was applied as in Boaventura et al. (2002).

The differences in infracommunity composition were tested through one-way permutational multivariate analysis of variance (PERMANOVA) of samples from the year 2000 (data from Paraguassú et al. (2002)) and 2012 (present study). A sequential sum of squares (Type I SS) was applied because host size was introduced as a covariable (ANCOVA model) due to the known effect of fish size-age on parasite burdens. The structures of parasite infracommunities between the samples per year (2012 and 2000) were compared using a model ( $1 \times 2$ factorial design, with year as a random factor) by testing for the main effects after 9999 permutations. The same model was tested for differences in dispersion using the PERMDISP routine (ANDERSON et al., 2008). Dispersion distances to centroids were measured, and each term in the analysis was tested using 9,999 permutations, with significant terms investigated using a posteriori pairwise comparisons with the PERMANOVA t-statistic (ANDERSON et al., 2008). Statistical analyses were carried out using the PRIMER ${ }^{\circledast}$ v.6 and PERMANOVA+ for PRIMER software (CLARKE; GORLEY, 2006; ANDERSON et al., 2008)

\section{Results}

\section{Community component}

A total of 25 species of metazoan parasites were recorded in the population of $P$. pagrus from the coastal zone of the municipality of Cabo Frio (Table 1). Sixteen species were recorded in both studies (Table 1), but Pseudoterranova sp. (larvae) (Nematoda, Anisakidae), 
Table 1. Comparison of the prevalence, intensity, mean intensity, abundance and infection site of metazoan parasites of Pagrus pagrus in the coastal region of the state of Rio de Janeiro, Brazil, collected in the study by Paraguassú et al. (2002) (P1) and in the present study (P2).

\begin{tabular}{|c|c|c|c|c|c|c|c|c|c|}
\hline \multirow{2}{*}{ Parasites } & \multicolumn{2}{|c|}{ Prevalence (\%) } & \multicolumn{2}{|c|}{ Intensity } & \multicolumn{2}{|c|}{ Mean intensity } & \multicolumn{2}{|c|}{ Mean abundance } & \multirow{2}{*}{ Infection site } \\
\hline & P1 & P2 & P1 & P2 & P1 & P2 & P1 & P2 & \\
\hline \multicolumn{10}{|l|}{ Digenea } \\
\hline Lecithochirium sp. & 5.5 & 6 & $1-6$ & $1-5$ & $2.8 \pm 2.2$ & $1.6 \pm 1.6$ & $0.1 \pm 0.8$ & $0.1 \pm 0.5$ & Stomach \\
\hline Parahemiurus merus & 34.4 & 10 & $1-29$ & $1-12$ & $4.5 \pm 6$ & $2.4 \pm 3.4$ & $1.5 \pm 4.1$ & $0.2 \pm 1.2$ & Intestine \\
\hline \multicolumn{10}{|l|}{ Monogenea } \\
\hline Anoplodiscus longivaginatus & 16.6 & 16 & $1-5$ & $1-4$ & $2.3 \pm 1.1$ & $1.5 \pm 0.8$ & $0.4 \pm 0.9$ & $0.2 \pm 0.6$ & Gills \\
\hline Benedenia sp. & 2.2 & 1 & $1-4$ & - & $2.5 \pm 2.1$ & 1 & $0.05 \pm 0.4$ & $0.01 \pm 0.1$ & Gills \\
\hline Echinopelma brasiliensis & 18.8 & 28 & $1-5$ & $1-2$ & $1.3 \pm 1$ & $1.2 \pm 0.4$ & $0.2 \pm 0.7$ & $0.3 \pm 0.5$ & Gills \\
\hline Encotyllabe spari & 57.7 & 37 & $1-23$ & $1-26$ & $4.3 \pm 4.3$ & $5.5 \pm 6$ & $2.4 \pm 3.9$ & $2 \pm 4.5$ & Pharyngeal plates \\
\hline Lamellodiscus baeri & 12.2 & 11 & $1-14$ & $1-6$ & $3 \pm 3.8$ & $2.1 \pm 1.6$ & $0.3 \pm 1.6$ & $0.2 \pm 0.8$ & Gills \\
\hline Polyabroides multispinosus & 10.1 & 8 & $1-2$ & $1-3$ & $1.1 \pm 0.3$ & $1.2 \pm 0.7$ & $0.1 \pm 0.3$ & $0.1 \pm 0.3$ & Gills \\
\hline \multicolumn{10}{|l|}{ Cestoda } \\
\hline Scolex polymorphus & 5.5 & - & $1-6$ & - & $2.6 \pm 2.3$ & - & $0.1 \pm 0.8$ & - & Mesenteries \\
\hline \multicolumn{10}{|l|}{ Acanthocephala } \\
\hline $\begin{array}{l}\text { Corynosoma australe } \\
\text { (cystacanth) }\end{array}$ & 4.4 & 5 & $1-15$ & $1-9$ & $8 \pm 5.9$ & $4.5 \pm 3.2$ & $0.3 \pm 1.9$ & $0.2 \pm 1.2$ & Mesenteries \\
\hline $\begin{array}{l}\text { Corynosoma cetaceum } \\
\text { (cystacanth) }\end{array}$ & 10 & - & $1-3$ & - & $1.3 \pm 0.7$ & - & $0.1 \pm 0.4$ & - & Mesenteries \\
\hline \multicolumn{10}{|l|}{ Nematoda } \\
\hline Hysterothylacium sp. (larval) & 93.3 & 90 & $1-100$ & $1-156$ & $12.8 \pm 14$ & $24 \pm 18$ & $11.9 \pm 14$ & $22 \pm 27$ & $\begin{array}{c}\text { Mesenteries and } \\
\text { liver }\end{array}$ \\
\hline Anisakis sp. (larval) & 7.7 & 40 & $1-7$ & $1-65$ & $2.9 \pm 1.9$ & $12 \pm 8$ & $0.2 \pm 0.9$ & $5 \pm 10$ & $\begin{array}{c}\text { Mesenteries and } \\
\text { liver }\end{array}$ \\
\hline Contracaecum sp.(larval) & - & 3 & - & $1-3$ & - & $1.6 \pm 1$ & - & $0.05 \pm 0.3$ & $\begin{array}{c}\text { Mesenteries and } \\
\text { liver }\end{array}$ \\
\hline Raphidascaris sp. (larval) & 8.8 & 20 & $1-3$ & $1-59$ & $1.6 \pm 0.7$ & $12 \pm 7$ & $0.1 \pm 0.5$ & $2.5 \pm 8$ & $\begin{array}{c}\text { Mesenteries and } \\
\text { liver }\end{array}$ \\
\hline Terranova sp. (larval) & - & 3 & - & $1-7$ & - & 3 & - & $0.09 \pm 0.7$ & $\begin{array}{c}\text { Mesenteries and } \\
\text { liver }\end{array}$ \\
\hline Pseudoterranova sp. (larval) & 6.6 & - & $1-5$ & - & $2.5 \pm 1.5$ & - & $0.1 \pm 0.7$ & - & Mesenteries \\
\hline \multicolumn{10}{|l|}{ Copepoda } \\
\hline Caligus haemulonis & 1.1 & - & - & - & 1 & - & $<0.01$ & - & Gills \\
\hline Caligus sepetibensis & 1.1 & - & - & - & 1 & - & $<0.01$ & - & Gills \\
\hline Clavellotis pagri & 1.1 & 36 & - & $1-10$ & 2 & $2.6 \pm 2.2$ & $<0.01$ & $0.9 \pm 1.8$ & Gill rakers \\
\hline Ergasilus sp. & 2.2 & 5 & $1-3$ & - & $2 \pm 1.4$ & 1 & $0.04 \pm 0.3$ & $0.05 \pm 0.2$ & Gills \\
\hline Lernanthropus caudatus & 21.1 & 14 & $1-7$ & $1-4$ & $2.5 \pm 1.9$ & $1.6 \pm 1.2$ & $0.5 \pm 1.3$ & $0.2 \pm 0.6$ & Gills \\
\hline Lerneocera sp. & 1.1 & - & - & - & 1 & - & $<0.01$ & - & Gills \\
\hline \multicolumn{10}{|l|}{ Isopoda } \\
\hline Cymothoid larval & - & 29 & - & $1-672$ & $70 \pm 135$ & $70 \pm 135$ & $20 \pm 79$ & $20 \pm 79$ & Gills \\
\hline Cymothoid not identified & 28.8 & 4 & $1-31$ & - & $6.9 \pm 7.9$ & 1 & $1.9 \pm 5.3$ & $0.04 \pm 0.1$ & Gills \\
\hline
\end{tabular}

Scolex polymorphus (Cestoda, Tetraphyllidea), Corynosoma cetaceum (Cystacanth) (Acanthocephala, Polymorphidae), Caligus haemulonis (Copepoda, Caligidae), C. sepetibensis., Lernaeocera sp. (Copepoda, Pennellidae) showed very low prevalence in the study of Paraguassú et al. (2002), and were not found in the current study, and the larval stage of Terranova sp. and unidentified larva of Cymothoid (Isopoda, Cymothoidae) were reported only in the current study (Table 1).

In both communities studied, the most abundant group was the anisakid nematodes (larval stages), representing 53.7\% of the total number of parasites collected in the current study and $59 \%$ in the study of Paraguassú et al. (2002). Hysterothylacium sp. was the dominant species, with 2178 specimens collected $(40.02 \%$ of all the parasites). Paraguassú et al. (2002) also reported that Hysterothylacium sp. was dominant in the metazoan community, with a total of 1075 specimens collected (56.5\% of all parasites). Furthermore, the abundance and prevalence of Hysterothylacium sp. have been positively correlated with host total length, while the prevalence of Parahemiurus merus was negatively correlated with host total length (Table 2). The sex of the host did not influence the prevalence and abundance of parasites in any of the studies $(Z c=-0.217, P=0.827)$. The total length of the hosts 
was $31.7 \pm 7.3(18-42 \mathrm{~cm})$ in the current study and $29.5 \pm 7.2$ $(16-50 \mathrm{~cm})$ in the study of Paraguassú et al. (2002), without significant differences $(t=1.962, \mathrm{P}=0.051)$.

\section{Infracommunities}

All the fish were parasitized by at least one parasite species. A total of 1,902 individual parasite specimens were collected in 2000 and 5,347 in 2012, with mean abundances of $21.1 \pm 17.4$ (1-100) and $143.5 \pm 53.4$ (1-672) respectively. Positive relationships between the total parasite abundance and the total body length of the fish were observed in both studies: current study $(r s=0.334$, $\mathrm{P}=0.001)$ and Paraguassú et al. (2002) $(r s=0.235, P=0.025)$. The mean richness of parasite species $(3.4 \pm 1.4),(3.5 \pm 1.2)$ was not correlated with total host body length $(r s=0.078, \mathrm{P}=0.437)$,
( $r s=0.102, P=0.335)$. The mean diversity of parasite species $(\mathrm{H})$ was $0.537 \pm 0.569$ and $0.306 \pm 0119$. The maximum diversity value was 1.136 and 0.644 in the current study and Paraguassú et al. (2002), respectively. The diversity of parasites was not correlated with total host body length ( $r s=0.051, \mathrm{P}=0.610)$, ( $r s=0.120$, $\mathrm{P}=0.260)$ and no significant difference in parasite diversity was observed between the sexes, in either study $(t=0.514, \mathrm{P}=0.773)$, $(t=0.873, \mathrm{P}=0.384)$ (Table 3$)$.

The infracommunities of ectoparasites (monogeneans and copepods) were separated to determine possible interspecific associations. Larval stages of nematodes and acanthocephalans, and adult digeneans were not included in this analysis because only one species had prevalence exceeding 10\% (Table 1). Among ectoparasites, three pairs of species shared significant positive covariation (Table 4) and two species pairs shared a significant

Table 2. Spearman's rank correlation coefficient $(r s)$ and Pearson's correlation coefficient $(r)$ values used to evaluate possible relationships between the total length of Pagrus pagrus, and the abundance and prevalence of its parasite community components, in the coastal region of the state of Rio de Janeiro, Brazil, in the study by Paraguassú et al. (2002) (P1) and in the present study (P2) (significance: P $\leq 0.05)$.

\begin{tabular}{lcccccccc}
\hline \multirow{2}{*}{\multicolumn{1}{c}{ Parasites }} & \multicolumn{4}{c}{$\mathbf{P 1}$} & \multicolumn{1}{c}{ P2 } \\
\cline { 2 - 8 } & $\boldsymbol{R}$ & $\mathbf{P}$ & $\boldsymbol{R}$ & $\mathbf{P}$ & $\boldsymbol{r}$ & $\boldsymbol{P}$ & $\mathbf{P}$ \\
\hline Encotyllabe spari & -0.062 & 0.561 & -0.877 & 0.051 & 0.129 & 0.198 & 0.177 & 0.078 \\
Anoplodiscus longivaginatus & -0.121 & 0.258 & -0.579 & 0.306 & -0.240 & 0.812 & 0.038 & 0.704 \\
Echinopelma brasiliensis & -0.105 & 0.321 & -0.592 & 0.292 & 0.110 & 0.276 & 0.121 & 0.232 \\
Lamellodiscus baeri & -0.005 & 0.962 & -0.389 & 0.517 & 0.036 & 0.715 & 0.044 & 0.658 \\
Parahemiurus merus & -0.051 & 0.633 & -0.899 & 0.038 & 0.120 & 0.231 & -0.191 & 0.056 \\
Lernanthropus caudatus & 0.120 & 0.257 & 0.269 & 0.661 & -0.169 & 0.105 & -0.154 & 0.125 \\
Hysterothylacium sp. & 0.093 & 0.379 & 0.149 & 0.811 & 0.307 & 0.001 & 0.298 & 0.002 \\
\hline
\end{tabular}

Table 3. Characteristics of the parasite infracommunities of Pagrus pagrus in the coastal region of the state of Rio de Janeiro, Brazil. $t=$ Student test value for comparison between the hosts, in the study by Paraguassú et al. (2002) (P1) and in the present study (P2).

\begin{tabular}{lccc}
\hline \multicolumn{1}{c}{ Characteristics/ species } & P1 & P2 & t \\
\hline Species richness & 22 & 19 &.--- \\
Total number of specimens & 1902 & 5347 & ---- \\
Mean parasite richness & $3.5 \pm 1.2$ & $3.4 \pm 1.4$ & -0.8034 \\
Total mean abundance & $21.1 \pm 17.4$ & $143.5 \pm 53.4$ & $-3.7727^{*}$ \\
Brillouin index (mean value) & $0.306 \pm 0.119$ & $0.537 \pm 0.569$ & -0.6541 \\
Dominant species & Hysterothylacium sp. & Hysterothylacium sp. & ---- \\
Berger-Parker Index (mean value) & $0.787 \pm 0.172$ & $0.786 \pm 0.185$ & $-5.9873^{*}$ \\
\hline
\end{tabular}

* Significant values.

Table 4. Spearman correlation coefficient values (rs) and chi-square values $(\chi 2)$ for co-occurrences of ectoparasite species pairs in Pagrus pagrus from the coastal region of the state of Rio de Janeiro, Brazil, in the study by Paraguassú et al. (2002) (P1) and in the present study (P2).

\begin{tabular}{|c|c|c|c|c|c|c|c|c|}
\hline \multirow{2}{*}{ Species pairs } & \multicolumn{4}{|c|}{ P1 } & \multicolumn{4}{|c|}{ P2 } \\
\hline & rs & $\mathbf{p}$ & $\chi^{2}$ & $\mathbf{p}$ & rs & $\mathbf{p}$ & $\chi^{2}$ & $\mathbf{p}$ \\
\hline Anoplodiscus longivaginatus - Echinopelma brasiliensis & 0.233 & 0.026 & 5.240 & 0.022 & -0.062 & 0.535 & $19215^{*}$ & 0.004 \\
\hline A. longivaginatus - Encotyllabe spari & -0.202 & 0.055 & 2.330 & 0.127 & 0.081 & 0.42 & 46.702 & 0.185 \\
\hline A. longivaginatus - Lamellodiscus baeri & 0.191 & 0.070 & 3.501 & 0.061 & 0.001 & 0.995 & 6.459 & 0.971 \\
\hline A. longivaginatus - Lernanthropus caudatus & 0.002 & 0.981 & 0.050 & 0.921 & -0.022 & 0.822 & 1.444 & 0.998 \\
\hline E. brasiliensis - E. spari & -0.126 & 0.235 & 0.201 & 0.654 & 0.073 & 0.468 & 18.116 & 0.871 \\
\hline E. brasiliensis - Lamellodiscus baeri & $0.277^{*}$ & 0.008 & $5.770^{*}$ & 0.016 & $0.353^{*}$ & 0.0003 & $34.68^{*}$ & 0.0001 \\
\hline E. brasiliensis - L. caudatus & 0.022 & 0.832 & 0.020 & 0.885 & -0.134 & 0.183 & 2.520 & 0.866 \\
\hline Encotyllabe spari-Lamellodiscus baeri & -0.065 & 0.542 & 0.780 & 0.377 & -0.059 & 0.558 & 32.312 & 0.999 \\
\hline E. spari - L. caudatus & $0.239^{*}$ & 0.022 & 1.120 & 0.291 & -0.109 & 0.278 & 152.713 & 0.999 \\
\hline Lamellodiscus baeri - L. caudatus & -0.130 & 0.220 & 1.250 & 0.263 & -0.058 & 0.563 & 1.757 & 1 \\
\hline
\end{tabular}

*significant values. 
positive association (Table 4). Prevalence and abundance were compared between studies (Table 5), and this showed that the prevalence and abundance were higher in the previous study.

The analysis of similarity (ANOSIM) was statistically significant $(\mathrm{P}<0.001)$. The NMDS ranking of 190 helminth infracommunities was based on abundance data that had previously been $[\log (\mathrm{x}+1)]$ transformed for the parasite species with prevalence $\geq 10 \%$ in both studies (Figure 1). The results show a clear similarity in the distribution of metazoan parasite infracommunities between the study by Paraguassú et al. (2002) and the current study, i.e. the same pattern held after 12 years. Correlation analysis between the abundance of each species of helminths and the axes of the NMDS showed that Encotyllabe spari and Hysterothylacium sp. were responsible for the major differences. This result was also found from the percentage contributions of the species (SIMPER) in which Hysterothylacium sp. accounted for $36.53 \%$ and Encotyllabe spari $23.77 \%$, thus contributing to the differences between the studies. The results from the PERMANOVA analysis showed that there was no interaction between year and host length between the study of Paraguassú et al. (2002) and the current study (Pseudo F 1.0062, P [perm] 0.5377) (Table 6). However the year factor levels differed between the years 2000 and 2012 (Pseudo F 6.0852, P [perm] 0.0003). PERMDISP was used to test the null hypothesis of no differences in dispersion of significant effect in the groups formed in the PERMANOVA analysis. The results from the PERMDISP analysis were not significant (Pseudo $F=0.51618$ ), which confirmed the results from NMDS (Figure 1).

\section{Discussion}

In comparing the data from the current study with that of the previous study by Paraguassú et al. (2002), we can affirm that the composition and structure of the community of metazoan parasites in this host species has shown temporal stability over

Table 5. Comparison of prevalence values $(\chi 2)$ and abundance values (Mann-Whitney $U$ test) for helminth community component species in Pagrus pagrus from the state of Rio de Janeiro, in the study by Paraguassú et al. (2002) (P1) and in the present study (P2) (significance: P $\leq 0.05)$.

\begin{tabular}{|c|c|c|c|c|c|c|}
\hline \multirow{2}{*}{ Parasites } & \multicolumn{3}{|c|}{ Prevalence } & \multicolumn{3}{|c|}{ Abundance } \\
\hline & $\chi^{2}$ & $\mathbf{P}$ & & $\mathbf{U}$ & $\mathbf{P}$ & \\
\hline Encotyllabe spari & 1.063 & 0.302 & $-\ldots$ & 3653.5 & 0.0151 & $\mathrm{P} 1>\mathrm{P} 2$ \\
\hline Anoplodiscus longivaginatus & 2.573 & 0.109 & --- & 4504 & 0.870 & -- \\
\hline Echinopelma brasiliensis & 0.87 & 0.351 & --- & 5006 & 0.105 & --- \\
\hline Lamellodiscus baeri & 1.943 & 0.163 & -- & 4535.5 & 0.967 & -- \\
\hline Parahemiurus merus & 55.841 & $<0.001$ & $\mathrm{P} 1>\mathrm{P} 2$ & 3443 & $<0.001$ & $\mathrm{P} 1>\mathrm{P} 2$ \\
\hline Lernanthropus caudatus & 18.251 & $<0.001$ & $\mathrm{P} 1>\mathrm{P} 2$ & 120 & 0.0005 & $\mathrm{P} 1>\mathrm{P} 2$ \\
\hline Hysterothylacium sp. & 164.476 & $<0.001$ & $\mathrm{P} 1>\mathrm{P} 2$ & 3572.5 & 0.0142 & $\mathrm{P} 1<\mathrm{P} 2$ \\
\hline
\end{tabular}

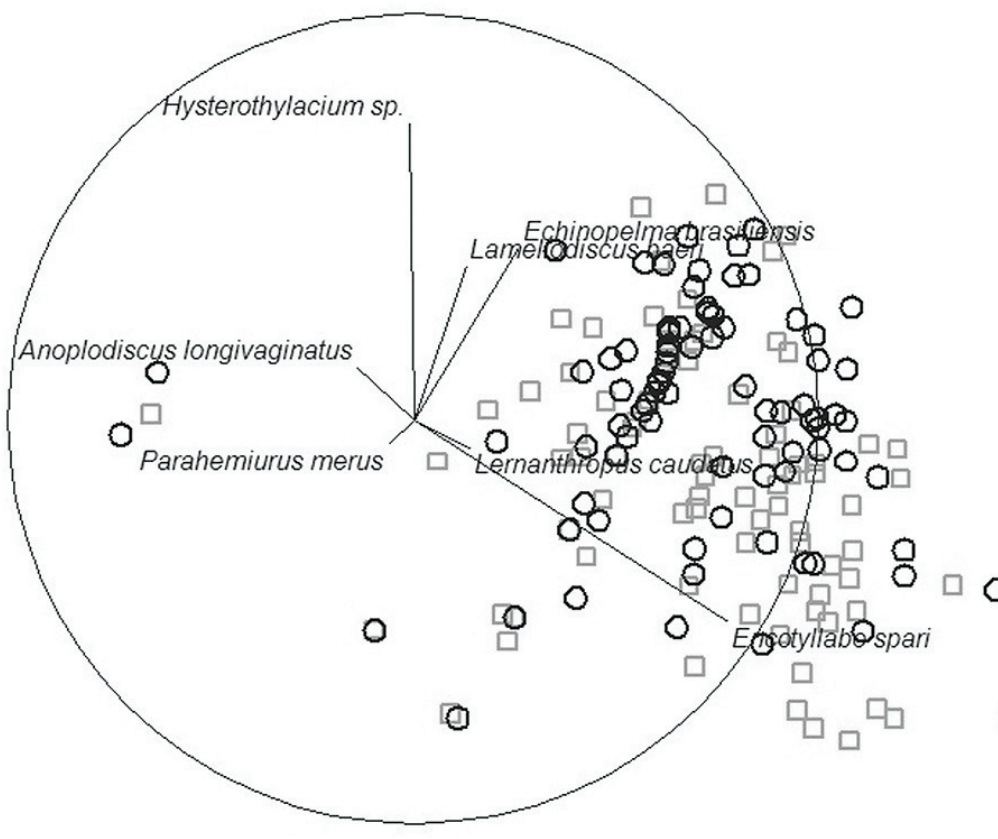

Figure 1. Non-metric multidimensional scaling (NMDS) plot on the first two axes based on the Bray-Curtis similarities of the log ( $x+1$ ) transformed parasite abundance data (stress $=0.13$ ). Vectors are Spearman correlations of helminth species abundances with the NMDS axes. (The circle represents a correlation of 1). Symbols denote sample membership as follows: $\square=$ year 2000 (data from Paraguassú et al., 2002); $\circ=$ year 2012 (data from current study). 
Table 6. Effects explaining variation in the abundance of seven parasite species, revealed by permutational multivariate analyses of variance (PERMANOVA) based on Bray-Curtis similarities to the $\log (\mathrm{x}+1)$ transformed abundance matrix. Only significant effects are listed. Permutational test for homogeneity of multivariate analysis (PERMDISP) was applied to test for differences in dispersion among groups formed by the factors that had significant effects in PERMANOVA.

\begin{tabular}{|c|c|c|c|c|}
\hline \multirow{3}{*}{ Source } & \multicolumn{2}{|c|}{ PERMANOVA } & \multicolumn{2}{|c|}{ PERMDISP } \\
\hline & \multicolumn{2}{|c|}{$2000-2012$} & \multicolumn{2}{|c|}{$2012-2000$} \\
\hline & Pseudo- $F$ & $P$ & Pseudo- $F$ & $P_{\text {(Disp }}$ \\
\hline Year & 6.0852 & 0.0001 & 0.51618 & NS \\
\hline Total length & 1.0062 & 0.5297 & ---- & ---- \\
\hline Year x Total length & 1.0559 & 0.3804 & -.-- & --- \\
\hline
\end{tabular}

the last 12 years. This can be seen from the fact that the same structure was reported in both studies and the dominance of larval stages of anisakid nematodes remained unchanged; from confirmation of the correlation between parasite abundance and total host body length, at the infracommunity level; from the absence of correlation between parasite infrapopulations size and host sex; and from the scarcity of interspecific associations in the parasite infracommunities. The only significant difference was in the abundance of larvae of anisakid nematodes, in relation to the study by Paraguassú et al. (2002). In the present study the abundance was doubled for anisakid nematodes.

Pagrus pagrus is a marine teleost fish, with demersal habits, which feeds mainly on crustaceans, fish and mollusks. This condition may explain the dominance of larval stages of anisakid nematodes, since the intermediate hosts in this life cycle are marine invertebrates (crustaceans or mollusks) (ANDERSON, 2000). Anisakid nematodes use fish as second intermediate or paratenic hosts, and the interrelationship between the components of the food chain enables transmission of parasites that have a complex life cycle. The difference in abundance between the two studies (current data and Paraguassú et al. (2002)) is reflected in the short sampling period in the present study, which focused on the summer. According to Costa et al. (1997), the spawning period for red porgy caught in the Cabo Frio region extends from November to January which would explain the differences in prevalence and abundance that coincide with the peak reproductive period of the host, since during this period the fish are more susceptible to parasitism caused, among other factors, by the stress of reproduction (LIZAMA et al., 2006). At this same time of year, there is the effect of the South Atlantic Central Water (SACW) phenomenon, which means that rearing takes place in a nutrient-rich mass, thus resulting in increased food availability throughout the food chain. Changes to the likelihood of infection could be due to the effect of changes in environmental conditions, particularly water temperature, on the life cycle of the parasites, but also to changes in host diet in cases of endoparasites that live in the digestive tract (TIMI et al., 2009).

The higher abundance of larvae of anisakid nematodes in the community of metazoan parasites of $P$. pagrus may suggest that the habits of this host favors its participation as an intermediate host in the parasite life cycle of this nematode group. This situation has also been recorded in the parasite infracommunities of some benthic marine fish from Rio de Janeiro (SILVA et al., 2000).

In the study of Paraguassú et al. (2002), the authors erroneously identified the larvae of Hysterothylacium as larvae of Contracaecum
(PARAGUASSÚ et al., 2002). In the current study, we examined specimens collected by Paraguassú et al. (2002) that were deposited in the Helminthological Collection of Oswaldo Cruz Institute (CHIOC). Larvae identified as Contracaecum by Paraguassú et al. (2002) (CHIOC No 34437) possess the excretory pore in the region of the nerve ring, which is a characteristic of larvae of Hysterothylacium sp. Thus, the diagnosis of larvae of Hysterothylacium was confused with larvae of Contracaecum sp. by Paraguassú et al. (2002). In species of Hysterothylacium, the excretory pore is located in the region of the nerve ring, thus differing from species of Contracaecum, in which it is located near the ventral interlabia (DEARDORFF; OVERSTREET, 1981; KLIMPEL; RUKERT., 2005; KLIMPEL et al., 2007; KNOFF et al., 2012; BORGES et al., 2012). According to Smith and Wooten (1978), although it is difficult to identify species based on morphological characters alone, it is even more difficult in relation to the larval stages. Species identification is especially important for larvae, because they have been implicated as causative agents of human anisakiasis. Anisakis simplex and Pseudoterranova decipiens are the principal species involved in human infection by nematodes of the family Anisakidae (ISHIKURA et al., 1993; ADAMS et al., 1997).

According to Poulin (1995), the potential diversity of parasites may also be associated with a variety of intermediate and definitive hosts. Furthermore, host size is most frequently correlated with the species richness of the community of parasites. Large-sized hosts can consume greater quantities of food than can small-sized hosts, and thus may be exposed to a greater range of infective stages of parasites. These larger hosts can also provide more space for the parasites, and thus harbor more species and offer greater variety of niches for occupation by the parasites. This also allows simultaneous occurrence of more species of parasites.

A positive correlation between parasite abundance and size of host was detected in the populations of red porgy studied by Paraguassú et al. (2002) and in the current study. As pointed out in the study by Polyanski (1961), quantitative and qualitative changes in parasitism are expected with fish growth. The significant positive correlation of mean number of parasites with total host body length indicates that larger hosts harbored greater numbers of parasite individuals and parasite species than did smaller ones. This can be attributed to the facts that larger (i.e. older) fish offer larger target areas for parasites transmitted by cercariae, ingest larger quantities of food, and have had more time to accumulate parasites than have smaller (i.e. younger) fish (ZANDER; KESTING, 1998; FIORILLO; FONT, 1999; POULIN, 2000; BUSH et al., 2003; FELLIS; ESCH, 2004; ZANDER, 2004). 
According to Saad-Fares and Combes (1992), in the case of the digeneans, this correlation might be influenced by changes to the fish diet. In addition, as mentioned by Cezar and Luque (1999), the digenean Parahemiurus merus showed a negative correlation between parasite abundance and host body size. This is in agreement with what was observed by Paraguassú (2002), who suggested that there was heterogeneity of dietary components and feeding behavior of $P$. pagrus between different age classes.

Absence of correlation between host sex and the prevalence and abundance of parasite community components of marine fish is common. In P. pagrus, the lack of such correlation might be attributed to similarity in ecological relationships (behavior, habitat and diet) between males and females, as stated by Luque et al. (1996). According to Poulin (1996), the influence of host sex on the prevalence and abundance of parasites is a topic hardly touched upon in community analysis discussions, and it is necessary to conduct experiments to show the influence of other factors, particularly fish physiology and behavior.

Comparison of the prevalence and abundance of common helminth species in P. pagrus, in the study by Paraguassú et al. (2002) and in the current study, revealed significant differences relating to the following species: Parahemiurus merus, Hysterothylacium sp., Lernanthropus caudatus and Encotyllabe spari. The qualitative similarity of the infracommunities of ectoparasites in $P$. pagrus from the municipality of Cabo Frio was shown at the genus level, with a complex of ectoparasite species (diplectanids, microcotylids, anoplodiscids, lernanthropids and caligids) that is a characteristic of other species of sparid fish. Lamellodiscus (Monogenea: Diplectanidae) has mainly been studied in sparids. Sparid fish are widely distributed in tropical and temperate coastal waters (NELSON, 2006). Diplectanids often show strict hostspecificity (OLIVER, 1992).

All the analyses confirmed and maintained the data of the study of Paraguassú et al. (2002), confirming the homogeneity of the structure and composition of the parasite community of $P$. pagrus. Variations in environmental conditions and their influence on the distribution of organisms that are part of the diet of red Porgy, involving the life cycle of parasites, can be considered to be important for observing the differences in abundance of some parasites between the current study and the study of Paraguassú et al. (2002).

\section{Acknowledgements}

Iris A. Soares was supported by a student fellowship from $\mathrm{CNPq}$ (Conselho Nacional de Pesquisa e Desenvolvimento Tecnológico, Brazil). Fabiano M. Vieira was supported by a postdoctoral fellowship from FAPERJ/CAPES (Fundação Carlos Chagas Filho de Amparo à Pesquisa do Estado do Rio de Janeiro/Coordenaçáo de Aperfeiçoamento de Pessoal de Nível Superior, Brazil). José L. Luque was supported by a research fellowship from CNPq.

\section{References}

Adams AM, Murrell KD, Cross JH. Parasites of fish and risks to public health. Rev Sci Tech Off Int Epiz 1997; 16(2): 652-60.
Anderson MJ, Gorley RN, Clarke KR. PERMANOVA for PRIMER: guide to statistical methods. Plymouth: PRIMER-E; 2008. 240 p.

Anderson RC. Nematode parasites of vertebrates: their development and transmission. 2nd ed. London: CAB Publishing; 2000. 672 p. http:// dx.doi.org/10.1079/9780851994215.0000

Ávila-da-Silva AO, Haimovici M. Diversidade e associação de espécies nas capturas de Espinhel-de-fundo. In: Haimovici M, Ávila-da-Silva AO, Rossi-Wongtschowski CLDB. Prospecção pesqueira de espécies demersais com espinhel-de-fundo na Zona Econômica Exclusiva da Regiāo Sudeste-Sul do Brasil. São Paulo: Instituto Oceanográfico; 2004. p. 93-110. (Série Documentos Revizee: Score Sul).

Boaventura D, Ré P, Fonseca LC, Hawkins SJ. Intertidal Rocky shore communities of the continental Portuguese coast: analysis of distribution patterns. Mar Ecol 2002; 23(1): 69-90. http://dx.doi.org/10.1046/ j.1439-0485.2002.02758.x

Borges JN, Cunha LFG, Santos HLC, Monteiro-Neto C, Santos CP. Morphological and molecular diagnosis of anisakid nematode larvae from cutlassfish (Trichiurus lepturus) off the coast of Rio de Janeiro, Brazil. PLoS One 2012; 7(7): e40447. PMid:22792329 PMCid:PMC3392247. http://dx.doi.org/10.1371/journal.pone.0040447

Bush AO, Aho JM, Kennedy CR. Ecological versus phylogenetic determinants of helminth parasite community richness. Evol Ecol 1990; 4(1): 1-20. http://dx.doi.org/10.1007/BF02270711

Bush AO, Fernández J, Esch GW, Seed JR. Parasitism: the diversity and ecology of animal parasites. Cambridge: Cambridge University Press; 2003.

Bush OA, Lafferty KD, Lotz JM, Shostak AW. Parasitology meets ecology on its own terms: Margolis et al. revisited. J Parasitol 1997; 83(4): 575-83. PMid:9267395. http://dx.doi.org/10.2307/3284227

Cezar AD, Luque JL. Metazoan parasites of the Atlantic Spadefish, Chaetodipterus faber (Teleostei: Ephippidae) from the coastal zone of the State of Rio de Janeiro, Brazil. J Helminthol 1999; 66(1): 14-20.

Clarke KR, Gorley RN. PRIMER V6: user manual - tutorial. Plymouth PRIMER-E; 2006.

Clarke KR, Warwick RM. Change in marine communities: an approach to statistical analysis and interpretation. Plymouth: PRIMER-E; 2001.

Clarke KR. Non-parametric multivariate analyses of changes in community structure. Aust J Ecol 1993; 18(1): 117-43. http://dx.doi. org/10.1111/j.1442-9993.1993.tb00438.x

Cohen SC, Justo MCN, Kohn A. South American Monogenoidea parasites of fishes, amphibians and reptiles. Rio de Janeiro: Oficina de Livros; 2013.

Costa PAS, Fagundes-Netto EB, Gaelzer LR, Lacerda OS, MonteiroRibas WM. Crescimento e ciclo reprodutivo do Pargo-rosa (Pagrus pagrus Linnaeus, 1758) na Regiáo do Cabo Frio, Rio de Janeiro. Neritica 1997; 11(1-2): 139-54

Deardorff TL, Overstreet RM. Larval Hysterothylacium (= Thynnascaris) (Nematoda: Anisakidae) from fishes and invertebrates in the Gulf of Mexico. Proc Helminthol Soc Wash 1981; 48(2): 113-26.

Fellis KJ, Esch GW. Community structure and seasonal dynamics of helminth parasites in Lepomis cyanellus and L. macrochirus from Charlie's Pond, North Carolina: Host size and species as determinants of community structure. J Parasitol 2004; 90(1): 41-9. PMid:15040665. http://dx.doi.org/10.1645/GE-3037 
Fiorillo RA, Font WF. Seasonal dynamics and community structure of helminths of spotted sunfish, Lepomis miniatus (Osteichthyes: Centrarchidae) from an oligohaline estuary in southeastern Louisiana, U.S.A. J Helminthol Soc Wash 1999; 66(2): 101-10.

International Union for Conservation of Nature and Natural Resources - IUCN. The IUCN Red List of Threatened Species. Version 2013.1 [online]. 2013 [cited 2013 Jul 25]. Available from: www.iucnredlist.org

Ishikura H, Kikuchi K, Nagasawa K, Ooiwa T, Takamiya H, Sato N, et al. Anisakidae and anisakidosis. In: Sun T. Progress in clinical parasitology. New York: Springer-Verlag; 1993. p. 43-102. PMid:8420604. http:// dx.doi.org/10.1007/978-1-4612-2732-8_3

Klimpel S, Kleinertz S, Hanel R, Rückert S. Genetic variability in Hysterothylacium aduncum, a raphidascarid nematode isolated from sprat (Sprattus sprattus) of different geographical area of the northeastern Atlantic. Parasitol Res 2007; 101(5): 1425-30. PMid:17674051. http:// dx.doi.org/10.1007/s00436-007-0662-0

Klimpel S, Rückert S. Life cycle strategy of Hysterothylacium aduncum to become the most abundant anisakid fish nematode in North Sea. Parasitol Res 2005; 97(2): 141-9. PMid:15986247. http://dx.doi.org/10.1007/ s00436-005-1407-6

Knoff M, Felizardo NN, Ińiguez AM, Maldonado A Jr, Torres EJL, Pinto RM, et al. Genetic and morphological characterisation of a new species of the genus Hysterothylacium (Nematoda) from Paralichthys isosceles Jordan, 1890 (Pisces: Teleostei) of the Neotropical Region, state of Rio de Janeiro, Brazil. Mem Inst Oswaldo Cruz 2012; 107(2): 18693. PMid:22415256. http://dx.doi.org/10.1590/S007402762012000200006

Kohn A, Fernandes BMM, Cohen SC. South American trematodes parasites of fishes. Rio de Janeiro: Imprinta Express; 2007. 318 p.

Lizama MAP, Takemoto RM, Pavanelli GC. Influence of the seasonal and environmental patterns and host reproduction on the metazoan parasites of Prochilodus lineatus. Braz Arch Biol Technol 2006; 49(4): 611-22. http:// dx.doi.org/10.1590/S1516-89132006000500011

Luque JL, Aguiar JC, Vieira FM, Gibson DI, Santos CP. Checklist of Nematoda associated with the fishes of Brazil. Zootaxa 2011; 3082: 1-88.

Luque JL, Amato JFR, Takemoto RM. Comparative analysis of the communities of metazoan parasites of Orthopristis ruber and Haemulon steindachneri (Osteichthyes: Haemulidae) from the southeastern Brazilian littoral: I. structure and influence of the size and sex of hosts. Rev Bras Biol 1996; 56: 279-92.

Luque JL, Poulin R. Linking ecology with parasite diversity in Neotropical fishes. J Fish Biol 2008; 72(1): 189-204. http://dx.doi. org/10.1111/j.1095-8649.2007.01695.x

Luque JL, Tavares LER. Checklist of Copepoda associated with fishes from Brazil. Zootaxa 2007; 1579: 1-39.

Luque JL. Biologia, epidemiologia e controle de parasitos de peixes. Rev Bras Parasitol Vet 2004; 13(S1): 161-4.

Manooch III CS, Hassler WW. Synopsis of biological data on the red porgy, Pagrus pagrus (Linnaeus). FAO Fish Synop 1978; 116: 1-19.

Menezes NA, Figueiredo JL. Manual de peixes marinhos do sudeste do Brasil: teleostei, 3. São Paulo: Museu de Zoologia da USP; 1980.

Muniz-Pereira LC, Vieira FM, Luque JL. Checklist of helminth parasites of threatened vertebrate species from Brazil. Zootaxa 2009; 2123: 1-45.
Nelson JS. Fishes of the world. 4th ed. Hoboken: John Wiley \& Sons; 2006. $601 \mathrm{p}$.

Oliver G. La spécificité parasitaire des Diplectanidae Bychowsky, 1957 (Monogenea, Monopisthocotylea): un facteur pour la connaissance des poissons-hôtes. Cybium 1992; 16(4): 361-6.

Paraguassú AR, Luque JL, Alves DR. Aspectos quantitativos do parasitismo por larvas de anisakídeos (Nematoda: Ascaridoidea: Anisakidae) no pargo, Pagrus pagrus (Osteichthyes: Sparidae) do litoral do estado do Rio de Janeiro, Brasil. Contrib Avulsas sobre Hist Nat Bras, Ser Zool 2000; 24: 1-8.

Paraguassú AR, Luque JL, Alves DR. Community ecology of metazoan parasites of red porgy Pagrus pagrus (L., 1758) (Osteichthyes, Sparidae) from the coastal zone, State of Rio de Janeiro, Brazil. Acta Sci, Biol sci 2002; 24(2): 461-7.

Polyanski YI. Ecology of parasites of marine fishes. In: Dogiel VA, Petrushevsky GK, Polyansky, YI. Parasitology offishes. Edinburgh: Oliver \& Boyd; 1961. p. 1-47.

Poulin R, Valtonen ET. The predictability of helminth community structure in space: a comparison of fish populations from adjacent lakes. Int J Parasitol 2002; 32(10): 1235-43. http://dx.doi.org/10.1016/ S0020-7519(02)00109-1

Poulin R. Phylogeny, ecology, and the richness of parasite communities in vertebrates. Ecol Monogr 1995; 65(3): 283-302. http://dx.doi. org/10.2307/2937061

Poulin R. Sexual inequalities in helminth infections: a cost of being a male? Am Nat 1996; 147(2): 287-95. http://dx.doi.org/10.1086/285851

Poulin R. Variation in the intraspecific relationship between fish length and intensity of parasitic infection: biological and statistical causes.J Fish Biol2000; 56(1): 123-37. http://dx.doi.org/10.1111/j.1095-8649.2000. tb02090.x

Saad-Fares A, Combes C. Abundance/host size relationship in a fish trematode community. J Helminthol 1992; 66(3): 187-92. http://dx.doi. org/10.1017/S0022149X00014541

Silva LGO, Luque JL, Alves DR. Ecologia da comunidade parasitária do peixe-espada Trichiurus lepturus (Osteichthyes: Trichiuridae) do litoral do estado do Rio de Janeiro, Brasil. Rev Bras Zooc 2000; 2: 115-33.

Smith JW, Wootten R. Anisakis and anisakiasis. Adv Parasitol. 1978; 16:93-163.

Timi JT, Lanfranchi AL, Etchegoin JA. Seasonal stability and spatial variability of parasites in Brazilian sandperch Pinguipes brasilianus from the northern Argentine sea: evidence for stock discrimination. J Fish Biol 2009; 74(6): 1206-25. PMid:20735626. http://dx.doi.org/10.1111/ j.1095-8649.2009.02190.x

Zander CD, Kesting V. Colonization and seasonality of goby (Gobiidae, Teleostei) parasites from the southwestern Baltic Sea. Parasitol Res 1998; 84(6): 459-66. PMid:9660135. http://dx.doi.org/10.1007/ s004360050430

Zander CD. Four-year monitoring of parasite communities in gobiid fishes of the south-western Baltic. II. Infracommunity. Parasitol Res 2004; 93(1): 17-29. PMid:15034786. http://dx.doi.org/10.1007/ s00436-004-1087-7

Zar JH. Biostatistical analysis. 3rd ed. New Jersey: Prentice Hall; 1996. 